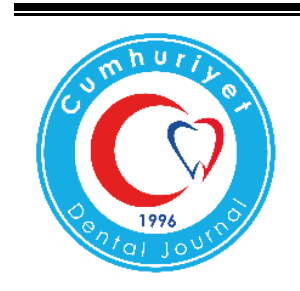

\section{USAGE OF ROTARY INSTRUMENTS IN ROOT CANAL THERAPY OF DECIDUOUS TEETH - REVIEW}

\section{ABSTRACT}

Maintaining the deciduous teeth in the mouth until the time of physiological exfoliation is of great importance for the health of the permanent dentition. Root canal treatment, also called pulpectomy, performed in cases of inflammation or necrosis of the deciduous teeth pulp, is indicated as a successful method to preserve the tooth functionally. Conventional pulpectomy procedure is performed with stainless steel files, however, the low elasticity of these files may cause undesirable canal shapes and the timetaking treatment period may lead to deterioration of the patient's cooperation, especially in pedodontics. Ni-Ti rotary instrument systems eliminate these disadvantages and provide better quality canal fillings in a shorter duration. The present article reviewed the studies that are comparing the traditional stainless steel files and Ni-Ti rotating instrument for the root canal treatment of deciduous teeth.

Keywords: Tooth, deciduous, dental instruments, root canal therapy, stainless steel.

\author{
*Ínci Kırmızı̈ül ${ }^{1}$ \\ Pinar Demir ${ }^{1}$
}

ORCID IDs of the authors: İ.K. 0000-0003-1236-965X

P.D. 0000-0003-2030-5429

${ }^{1}$ Department of Pedodontics, Faculty of
Dentistry, Inonu University Malatya, Turkey

Received : : 17.04 .2019

Accepted $\quad: 24.06 .2019$ 


\section{INTRODUCTION}

The early loss of deciduous teeth in pedodontics is an undesirable condition leading to serious negative outcomes. Deciduous teeth contribute tofunction, phonation, and aesthetics as long as they remain in the mouth. The earlyloss of deciduous teeth in children may result in various harmful habits, an impaired eruption of permanent dentition, lack of space and crowdings. ${ }^{1-4}$

Pulpectomy, which is recommended for pulpitis or necrosis of deciduous tooth, is a more conservative treatment method compared to tooth extraction. As for permanent teeth, the purpose of root canal treatment for deciduous teeth is to provide the disinfection of root canals by eliminating microorganisms, to prevent the reinfection of the tooth with a sealed filling and restoration, and to maintain the functionality of the tooth by preserving the health of periapical tissues. ${ }^{1,2,4}$ However, unlike permanent teeth, factors such as deciduous teeth's short canal lengths, divergent and curved roots, thinner and more easily abradable dentin walls, canals with more variability and irregularity, physiological root resorption and limited duration for treatment in pediatric patients, render canal treatment more challenging. ${ }^{2,5-7}$

Despite these negative factors, pulpectomy is the recommended and performed method for deciduous teeth with success rates ranging from $68 \%$ to $100 \% .^{5,7}$

An ideal pulpectomy technique for the root canal treatment of the primary teeth should be completed in a short time period, provide an effective shaping and debridement without weakening teeth structure, not compromise the successor tooth germ, and ensure that the tooth remains in the mouth until its physiological loss with minimal complication. ${ }^{3,7}$

The traditional method for root canal treatment is stainless steel hand instruments. Stainless steel files can cause distruptions in the original shape of root canals and perforations due to their low flexibility. Ni-Ti rotary instrument systems, which were developed for solving the limitations of stainless steel files and used since the 1980s, provide more successful and better conical shaping, better quality debridement and filling in a short time owing to their high flexibility. ${ }^{2,3,5,7,8}$

The studies comparing traditional stainless steel files with Ni-Ti rotary instruments for root canal treatment are mostly focused on permanent teeth. The number of studies evaluating the use of rotary instruments for deciduous teeth is limited. ${ }^{5}$ The aim of this article is to present and discuss the advantages and disadvantages of the use of stainless steel files and Ni-Ti rotary instruments in the primary root canal treatments in the light of the previous studies.

\section{Rotary Instruments Used in Root Canal Therapies}

Over the years, Ni-Ti rotary systems have been introduced with a wide range of designs and usage techniques. ${ }^{9-11}$ ProFile, Hero642 and FlexMaster are the 1st generation rotary systems. ProFile has triple U shaped cross-section, while Hero642 and FlexMaster have triangular cross-section. They create smooth root canal walls and cause low procedural errors, but contain numerous files for root canal preparation. ${ }^{9}, 10$ Second generation rotary systems include RaCe, ProTaper, K3, Hero Shaper and Mtwo. ${ }^{9,10}$ These systems have fewer instruments with active cutting edges. They provide faster preparation and preserve the original shape of even the curved root canals. ${ }^{9}$ While designing the 3rd generation rotary systems, the producers focused on to reduce cyclic fatigue and separation risk of the instruments. ${ }^{9}$ The reciprocal movement idea inspired the producers to develop the 4th generation rotary systems. ${ }^{9,12}$ Reciprocating motion is a back-andforth motion, in clockwise and anti-clockwise direction. It reduces the risk of instrument separation, due to avoidance of continuous dentinal over engagement. ${ }^{13}$ Wave-One, Reciproc and SAF are the examples of 4th generation of rotary systems. ${ }^{9}$ The fifth generation rotary files like Revo-S and ProTaper Next, have special designs. Revo-S has only three instruments with asymmetrical cross-section and makes snake-like movement in root canals. ${ }^{10}$ ProTaper Next has rectangular off-center cross-section and its offset mass provides greater strength, improved flexibility, and resistance to cyclic fatigue. ${ }^{10,12}$ 


\section{Efficacy in Cleansing and Shaping}

Root canal shaping is considered to be one of the most important steps of canal treatment. It is important to remove the necrotic pulp together with the infected root dentin and to give a shape providing easy debridement in the root cavity and a quality filling. ${ }^{14}$ Along with proper shaping and debridement, the removal of organic debris in the canals and reduction of the number of microorganisms are essential for the success of endodontic treatment. ${ }^{4,15,16}$

Comparing rotary instruments with manual instruments in terms of intracavitary microorganism elimination demonstrated that both systems significantly reduced the number of microorganisms and that there was no statistical difference between them. ${ }^{17-19}$

Conventional stainless steel files were reported to remove more dentin tissue, especially in the coronal region. Although the difference between them and rotary instruments was not significant, stainless steel files were indicated to provide more efficient cleaning., ${ }^{40-22}$ However, there are also studies comparing ProFile, ProTaper, Hero Shaper rotary instruments and Ktype stainless steel files which reported that rotary instruments provided more effective cleaning in a statistically significant manner. ${ }^{23}$ Some researchers recommend the hybrid method in which two systems are used in combination for root canal preparation. The hybrid method was reported to clean smears and debris better and to create more successful canal filling with better shaping. ${ }^{17,24}$

Rotary instruments working with reciprocal movements such as Reciproc and WaveOne were shown to provide more successful cleansing compared to rotary instruments working with rotation movement and were recommended to be used for deciduous teeth. ${ }^{16,25}$

In conclusion, the studies comparing the cleansing efficacies of rotary instruments and stainless steel files revealed no statistically significant difference between the two methods. ${ }^{15,26-28}$ However, more conical canal shape, and smooth canal walls were obtained with rotary instruments compared to stainless steel files. Thereby, they were reported to provide better quality filling and sealing, thus increasing clinical success. ${ }^{8,16,23,29}$

\section{Filling Volume and Efficacy}

The complex morphology of root canals and dissoluble characteristics of the canal filling material cause insufficient filling and failure in apical sealing. This increases the importance of mechanical preparation for the root canal treatment of deciduous teeth. ${ }^{30}$

Although there is a study which found no significant difference in terms of apical sealing quality between ProTaper, Mtwo rotary instruments and K-type files ${ }^{31}$, most studies reported that filling density and sealing quality were higher when the tooth preparation was performed using the rotary instruments or the hybrid method. ${ }^{24,30,32,33}$

The Mtwo rotary instrument system was reported to show better sealing and higher filling volume in a study comparing Mtwo and K-type files, although, gaps were observed in the canals of the two groups after filling. ${ }^{32}$

Although apical leakage was observed in all deciduous teeth prepared with Hero642, Race, Mtwo, ProTaper rotary instruments and K-type files, the highest leakage value occurred with Ktype files. While Hero642 and Mtwo yielded a significantly lower leakage value, the system providing the most successful apical sealing was stated to be Hero $642 .{ }^{30}$

The preparation is more difficult in the mesial canals of deciduous molar teeth which are generally narrower. In one study, deciduous teeth were prepared with FlexMaster rotary files and Ktype files, and completeness of canal filling of molar mesial canals was found to be significantly higher in the rotary group. Preparation with Ktype files were noted to result in more incomplete fillings. ${ }^{33}$

More successful filling and better quality apical sealing with rotary instruments are contributed to the conical form obtained by the high taper angle of the rotary instruments. By this way, the flow of the canal paste into the canal is facilitated, the filling density and volume is increased, and apical leakage is decreased..$^{30,33}$ 


\section{Overflow of Irrigating Solution and Debris from Apical Region}

A study on deciduous molar teeth comparing Revo-S, Mtwo, ProTaper Next rotary instrument systems, and K-type stainless steel hand instruments showed that K-type files caused significantly more debris overflow than the rotary instrument systems. The least amount of debris overflow was measured in the ProTaper Next group among the rotary instrument systems used in the study. ${ }^{34}$

Studies have shown that there is not a preparation instrument or a method that does not cause apical debris and irrigating solution overflow, and that hand files do not provide an advantage to rotary systems. Therefore, the researchers reported that the rotary systems could be preferred in the root canal treatment of deciduous teeth. ${ }^{34-36}$

Further studies evaluating the instruments used in the root canal treatment of deciduous teeth in terms of the apical extrusion of irrigant and debris are needed.

\section{Postoperative Pain}

Postoperative pain was evaluated at the 6th, 12th, 24th, 48th and 72nd hours and 1 week postoperatively in a study in which deciduous teeth were prepared with stainless steel hand instrument and Revo-S rotary instrument system. The patient group whose root canals were prepared with hand instruments reported more severe postoperative pain, except in the 72 nd hour and 1st week measurements. Postoperative pain decreased in time with both methods. ${ }^{37}$

\section{Instrument Failure and Root Perforation}

The dentin walls are thin and can be easily eroded in the roots of deciduous teeth. Therefore, aggressive erosive root instruments can cause perforations in the canal walls of deciduous teeth. Also, canal instruments with less flexibility may cause undesirable canal shapes and perforations in the curved deciduous teeth canals. Due to the insufficient flexibility of traditional stainless steel hand instruments, Ni-Ti rotary instrument systems with higher elasticity were developed. ${ }^{5}$

Fractures are encountered more commonly in the Ni-Ti rotary instrument systems as a result of compression within the canal secondary to continuous rotation movement while distortion and deformations occur more frequently due to insufficient elastic properties of stainless steel hand instruments. ${ }^{8,23}$

In a study comparing ProTaper and K-type files, it was reported that there was no significant difference between the two systems in terms of perforation and instrument fracture. ${ }^{38}$ Another study evaluating Reciproc rotary instrument system working with reciprocal movement and Mtwo rotary instrument system working with rotation movement revealed no deformation or fracture in the instruments. ${ }^{16}$ Since reciprocating instruments move back and forth in the canal, the risk of fracture decreases. Also, they provide less canal transportation compared to the rotary instruments working with rotation movement. ${ }^{13}$

A study comparing K3 rotary instrument system (.02 taper and.04 taper) and K-type files (.02 taper) revealed no instrumental fracture and indicated that the rate of perforation increased as the taper angle increased. ${ }^{20}$ The Hero642, ProTaper and K-files were compared in terms of preparation safety and no perforation or instrument fracture were observed in the Hero642 group. This was contributed to the lesser conicity and higher elasticity of Hero642 rotary instrument files. Both perforation and instrument fracture were observed in the K-type file group. Perforation was observed most commonly in the ProTaper group, the reason for this was shown to be the aggressive erosive blades and high taper angle of the ProTaper files. The high taper angle was stated to increase the bending resistance and cause undesirable lateral forces during rotation movement, especially in curved canals such as deciduous teeth have. ${ }^{5}$

A case report suggested that the Kedo-S rotary instrument system designed specifically for pediatric patients reduced the risk of instrument failure, perforation and undesirable canal shaping, and that its use for deciduous teeth was safer than rotating tools designed for permanent teeth. The reason for this was shown to be $16 \mathrm{~mm}$ short files facilitating its use in pediatric patients and three files with different taper angles adapting to the thin and curved canals of the deciduous teeth. ${ }^{39}$ 
In order not to cause iatrogenic errors in the curved, thin and erosive canal walls of the deciduous teeth, flexible files/systems with low taper angle that does not remove excess dentin tissue should be selected. ${ }^{5,20}$

\section{Preparation Time}

The duration of preparation in pediatric patients is of great importance in terms of the cooperation of the child and the quality of treatment. ${ }^{3,40}$ The duration of preparation in root canal treatments depends on the technique used, physician's experience and the type and number of instruments used. ${ }^{25}$

Many studies were conducted to compare the preparation times of conventional stainless steel files and Ni-Ti rotary instruments and these stated that shorter preparation could be performed with rotary instruments. These studies compared Ni-Ti rotary instrument systems such as ProTaper, Mtwo, Hero642, FlexMaster, K3 and SAF with Kfiles. $8,15,20,21,23,28,29,31,33,38$

Only a single study compared the H-type stainless steel files and Mtwo rotary instruments and reported shorter preparation time for H-type files. The reason for this was the fact that the time of instrument change was also included in the measured time. ${ }^{4}$

The preparation times of the Hero642, ProTaper rotary instruments and K-files were evaluated and the longest time was observed in Kfiles, while the lowest preparation time was measured in the Hero642 group. This was contributed to the fact that the Hero642 rotary instrument system contained fewer instruments and that it was easier to apply. ${ }^{5}$

The Kedo-S rotary instrument system, which is including few instruments, was recommended to be used for pediatric patients. ${ }^{39}$ The Kedo-S rotary instrument system was noted to provide better quality sealing in the deciduous tooth root canals compared to the K-type and H-type files. ${ }^{40}$

When the rotary instruments were compared among themselves in terms of movement type, rotary instrument system working with reciprocation movement such as Reciproc and Wave-One were reported to allow faster preparation than those working with rotation movement. ${ }^{13,16,25,35}$

$\mathrm{Ni}-\mathrm{Ti}$ rotary instrument systems shorten the treatment time compared to the traditional method using stainless steel files, thereby increasing patient cooperation and reducing physician's fatigue. ${ }^{8}$

\section{CONCLUSIONS}

The root canal treatment of deciduous teeth can be performed with traditional stainless steel files as well as Ni-Ti rotary instrument systems.

The advantages of Ni-Ti rotary instruments are; maintaining the original shape of the canal owing to their flexible structure, reducing iatrogenic errors with the preservation of original anatomy, effective cleansing of irregular canals of deciduous molar teeth, ensuring uniform filling and reducing apical leakage thanks to conical shaped preparation and smooth canal walls, increased patient cooperation with rapid treatment and reduced fatigue of physician. ${ }^{2,3,13,25}$

Factors such as increasing the risk of instrument fracture because of wrong applications since it is a sensitive technique, being expensive and requiring experience are the disadvantages of Ni-Ti rotary instruments. , $^{2,325,41}$

Patient cooperation is a very important factor determining the success of the treatment, especially in pediatric dentistry. With the use of Ni-Ti rotary instruments for the root canal treatment of deciduous teeth, better quality treatments can be performed in a shorter time period. $2,3,13,25,27,41$

\section{ACKNOWLEDGEMENTS}

None

\section{CONFLICT OF INTEREST STATEMENT}

None

\section{Süt Dişlerinin Kanal Tedavilerinde Döner Alet Kullanım - Derleme}

$\ddot{O} Z$

Süt dişlerinin fizyolojik düşme zamanlarina kadar ă̆ızda tutulması daimi dentisyonun sağlĭğ açısından büyük önem taşımaktadır. Süt dişi pulpasinın iltihabı veya nekrozu gibi durumlarda uygulanan kök kanal tedavisi, diğer adiyla pulpektomi, dişin fonksiyonunun devaminı sağlayan başarılı bir yöntem olarak gösterilmektedir. Geleneksel pulpektomi uygulaması paslanmaz çelik eğelerle yapllmaktadır, ancak bu eğelerin düşük elastikiyetleri nedeniyle istenmeyen 
kanal şekilleri oluşabilmekte, zaman alan tedavi süresi ise özellikle pedodontide hastanin kooperasyonunun bozulmasina sebep olabilmektedir. Ni-Ti döner alet sistemleri bu dezavantajları ortadan kaldirarak daha kisa zamanda daha kaliteli kanal dolumlar sağlayabilmektedir. Bu makalede, süt dişi kanal tedavisinde geleneksel paslanmaz çelik eğeler ile Ni-Ti döner aletlerin karşılaştırıldiğg çalışmalar derlenmiştir. Anahtar Kelimeler: Süt dişi, dental araçlar, kök kanal tedavisi, paslanmaz çelik.

\section{REFERENCES}

1. Brustolin JP, Mariath AA, Ardenghi TM, Casagrande L. Survival and factors associated with failure of pulpectomies performed in primary teeth by dental students. Braz Dent J. 2017;28:121-8.

2. Garip G, Nur BG, Altunsoy M, Ok E. Süt dişlerinde nikel titanyum döner aletlerinin kullanımının değerlendirilmesi. Atatürk Üniv Diş Hek Fak Derg. 2015;25:249-257.

3. George S, Anandaraj S, Issac JS, John SA, Harris A. Rotary endodontics in primary teeth - a review. Saudi Dent J. 2016;28:12-17.

4. Katge F, Chimata VK, Poojari M, Shetty S, Rusawat B. Comparison of cleaning efficacy and instrumentation time between rotary and manual instrumentation techniques in primary teeth: an in vitro study. Int J Clin Pediatr Dent. 2016;9:124-127.

5. Arıkan V, Akçay M, Zeren AE, Sarı Ş, Çelik BN. Süt dişi kök kanal tedavisinde Hero 642 Protaper Ni-Ti döner sistemler ve $\mathrm{K}$ tipi eğenin preparasyon güvenliğgi ve süresi açısından in-vitro olarak karşılaştırılması. AÜ Diş Hek Fak Derg. 2010;37:89-96.

6. Asgary S, Fazlyab M. Endodontic management of an infected primary molar in a child with agenesis of the permanent premolar. Iran Endod J. 2017;12:119-122.

7. Kuo C, Wang Y, Chang H, Huang G, Lin C, Li U, Guo M. Application of Ni-Ti rotary files for pulpectomy in primary molars. J Dent. 2006;1:10-15.

8. Nagaratna PJ, Shashikiran ND, Subbareddy VV. In vitro comparison of NiTi rotary instruments and stainless steel hand instruments in root canal preparations of primary and permanent molar. J Indian Soc Pedod Prev Dent. 2006;24:186-191.

9. Kuzekanani M. Nickel-titanium rotary instruments: development of the single-file systems. J Int Soc Prev Community Dent. 2018;8:386-390.
10. Singh K, Bindra S, Singh G, Kaur H. Endodontic rotary systems - a review. J Adv Med Dent Scie Res. 2016;4:62-66.

11. Soni M, Hegde S, Mathew S, Madhu K. Rotary systems: an insight. J Dent Orofac Res. 2014;10:16-21.

12. Ruddle CJ, Machtou P, West JD. The shaping movement: fifth-generation technology. Dent Today. 2013;32:1-8.

13. Prabhakar AR, Yavagal C, Dixit K, Naik SV. Reciprocating vs rotary instrumentation in pediatric endodontics: cone beam computed tomographic analysis of deciduous root canals using two single-file systems. Int J Clin Pediatr Dent. 2016;9:45-49.

14. de Melo Ribeiro MV, Silva-Sousa YT, Versiani MA, Lamira A, Steier L, Pecora JD, de Sousa-Neto MD. Comparison of the cleaning efficacy of selfadjusting file and rotary systems in the apical third of oval-shaped canals. J Endod. 2013;39:398-401.

15. Ramezanali F, Afkhami F, Soleimani A, Kharrazifard MJ, Rafiee F. Comparison of cleaning efficacy and instrumentation time in primary molars: Mtwo rotary instruments vs. hand K-files. Iran Endod J. 2015;10:240-243.

16. Ramazani N, Mohammadi A, Amirabadi F, Ramazani M, Ehsani F. In vitro investigation of the cleaning efficacy, shaping ability, preparation time and file deformation of continuous rotary, reciprocating rotary and manual instrumentations in primary molars. J Dent Res Dent Clin Dent Prospects. 2016;10:49-56.

17. Pinheiro SL, Araujo G, Bincelli I, Cunha R, Bueno

C. Evaluation of cleaning capacity and instrumentation time of manual, hybrid and rotary instrumentation techniques in primary molars. Int Endod J. 2012;45:379-385.

18. Pinheiro SL, Silva JN, Goncalves RO, Villalpando KT. Manual and rotary instrumentation ability to reduce Enterococcus Faecalis associated with photodynamic therapy in deciduous molars. Braz Dent J. 2014;25:502-507.

19. Subramaniam P, Tabrez TA, Babu KL. Microbiological assessment of root canals following use of rotary and manual instruments in primary molars. J Clin Pediatr Dent. 2013;38:123-127.

20. Selvakumar H, Kavitha S, Thomas E, Anadhan V, Vijayakumar R. computed tomographic evaluation of $\mathrm{K} 3$ rotary and stainless steel $\mathrm{K}$ file instrumentation in primary teeth. J Clin Diagn Res. 2016;10:5-8. 
21. Kaya E, Elbay M, Yigit D. Evaluation of the SelfAdjusting File system (SAF) for the instrumentation of primary molar root canals: a micro-computed tomographic study. Eur J Paediatr Dent. 2017;18:105-110. 22. Canoglu H, Tekcicek MU, Cehreli ZC. Comparison of conventional, rotary, and ultrasonic preparation, different final irrigation regimens, and 2 sealers in primary molar root canal therapy. Pediat Dent. 2006;28:518-523.

23. Musale PK, Mujawar SA. Evaluation of the efficacy of rotary vs. hand files in root canal preparation of primary teeth in vitro using CBCT. Eur Arch Paediatr Dent. 2014;15:113-120.

24. Deshpande AN, Joshi NH, Naik KS. In vitro comparative evaluation of cleaning efficacy and volumetric filling in primary molars: cone beam computed tomography evaluation. Contemp Clin Dent. 2017;8:33-37.

25. Katge F, Patil D, Poojari M, Pimpale J, Shitoot A, Rusawat B. Comparison of instrumentation time and cleaning efficacy of manual instrumentation, rotary systems and reciprocating systems in primary teeth: an in vitro study. $\mathbf{J}$ Indian Soc Pedod Prev Dent. 2014;32:311-316.

26. Subramaniam P, Girish Babu KL, Tabrez TA. Effectiveness of rotary endodontic instruments on smear layer removal in root canals of primary teeth: a scanning electron microscopy study. J Clin Pediatr Dent. 2016;40:141-146.

27. Azar MR, Safi L, Nikaein A. Comparison of the cleaning capacity of Mtwo and ProTaper rotary systems and manual instruments in primary teeth. Dental Res J (Isfahan). 2012;9:146-151.

28. Azar MR, Mokhtare M. Rotary Mtwo system versus manual K-file instruments: efficacy in preparing primary and permanent molar root canals. Indian $\mathbf{J}$ Dent Res. 2011;22:363.

29. Crespo S, Cortes O, Garcia C, Perez L. Comparison between rotary and manual instrumentation in primary teeth. J Clin Pediatr Dent. 2008;32:295-298.

30.Zeren AE, Çelik BN, Arıkan V, Akçay M, Sarı Ş. Dört farklı döner alet sistemi ve K tipi eğe ile prepare edilen süt azı dişlerinde apikal mikrosızıntının in vitro olarak karşılaştırılması. AÜ Diş Hek Fak Derg. 2012;39:7-15.

31. Govindaraju L, Jeevanandan G, Subramanian EMG. Comparison of quality of obturation and instrumentation time using hand files and two rotary file systems in primary molars: a single-blinded randomized controlled trial. Eur J Dent. 2017;11:376-379.

32. Poornima $P$, Disha $P$, Nagaveni NB, Roopa KB, Bharath KP, Neena IE. Volumetric analysis of hand and rotary root canal instrumentation and filling in primary teeth using Spiral Computed Tomography - an invitro study. Int J Paediatr Dent. 2016;26:193-198.

33. Makarem A, Ravandeh N, Ebrahimi M. Radiographic assessment and chair time of rotary instruments in the pulpectomy of primary second molar teeth: a randomized controlled clinical trial. J Dent Res Dent Clin Dent Prospects. 2014;8:84-89.

34. Topçuoğlu G, Topçuoğlu HS, Akpek F. Evaluation of apically extruded debris during root canal preparation in primary molar teeth using three different rotary systems and hand files. Int $\mathbf{J}$ Paediatr Dent. 2016;26:357-363.

35. Kucukyilmaz E, Savas S, Saygili G, Uysal B. Evaluation of apically extruded debris and irrigant produced by different nickel-titanium instrument systems in primary teeth. J Contemp Dent Pract. 2015;16:864-868.

36. Singh A, Arunagiri D, Pushpa S, Sawhny A, Misra A, Khetan K. Apical extrusion of debris and irrigants using ProTaper hand, M-two rotary and WaveOne single file reciprocating system: an ex vivo study. J Conserv Dent. 2015;18:405-408.

37. Topcuoglu G, Topcuoglu HS, Delikan E, Aydinbelge M, Dogan S. Postoperative pain after root canal preparation with hand and rotary files in primary molar teeth. Pediatr Dent. 2017;39:192-196.

38. Arıkan V, Akçay M, Zeren A, Sarı Ş. Comparison of A Ni-Ti rotary system (ProTaper) with $\mathrm{K}$ Files in primary tooth root canal preparation: an in vitro study. Turkiye Klinikleri J Dental Sci. 2011;17:170-176.

39. Jeevanandan G. Kedo-S paediatric rotary files for root canal preparation in primary teeth - case report. $\mathbf{J}$ Clin Diagn Res. 2017;11:3-5.

40. Panchal V, Jeevanandan G, Subramanian E. Comparison of instrumentation time and obturation quality between hand $\mathrm{K}$-file, $\mathrm{H}$-files, and rotary Kedo$S$ in root canal treatment of primary teeth: a randomized controlled trial. J Indian Soc Pedod Prev Dent. 2019;37:75-79.

41.Barr ES, Kleier DJ, Barr NV. Use of nickeltitanium rotary files for root canal preparation in primary teeth. Pediatr Dent. 2000;22:77-78. 